\title{
Tarekat Syattariyah dan Alawiyah: Pemikiran dan Dinamika Jaringan Islam di Sulawesi Tengah Abab XVII-XX M
}

\author{
Muhammad Nur Ichsan Azis ${ }^{1}$ Salmin Djakaria²
}

${ }^{1}$ Balai Arkeologi Provinsi Sulawesi Selatan

${ }^{2}$ Balai Arkeologi Provinsi Sulawesi Utara

Correspondence:

Muhammad Nur Ichsan Azis

Balai Arkeologi Provinsi

Sulawesi Selatan

icchankazis18@gmail.com

\section{Article History:}

Received 29 Oktober 2021

Revised 29 November 2021

Accepted 7 Desember 2021

\begin{abstract}
Islamic thought in the Central Sulawesi region grew since the 17th century. Dato Karama laid the foundation for the appearance of Islam in Central Sulawesi. Meanwhile, Sayyid Idrus bin Salim Aljufrie continued the relay of Islamic development in Central Sulawesi by developing modern Islamic education in the 20th century. Both have their own characteristics in determining the development of Islam through adaptive and modernist Islamization methods. In the end, Islam became an integral institution among the people of Central Sulawesi. The two figures are also known as followers of the Syattariyah and Alawiyyah orders. This paper utilizes the historical method as described by Kuntowijoyo (2006), that historical events do not only show the periodic side of an event, but the direction and motion of events that can change a phenomenon or event from an object. A historical event requires auxiliary science to dissect every side of events that have occurred in the past. Therefore, Sartono (1982) concludes that historical narratives should ideally be written by paying attention to the explanation of causality and determiners in one event. Finally, this paper concludes that the success of the Islamization axis in Sulawesi is not just a historical chronicle, it has further implications for an optimistic historiography in which the thoughts and dynamics of the Islamic movement in Central Sulawesi up to the 20th century strengthened the position and legacy of Islamic historical thought in Central Sulawesi.

Keywords: Islamic thought, Central Sulawesi, tarekat, Syattariyah, Alawiyyah
\end{abstract}

\section{Abstrak}

Pemikiran Islam di kawasan Sulawesi Tengah tumbuh sejak abad XVII. Dato Karama meletakkan dasar perwajahan Islam di Sulawesi tengah. Sedangkan Sayyid Idrus bin Salim Aljufrie melanjutkan estafet perkembangan Islam di Sulawesi Tengah dengan mengembangkan pendidikan Islam modern pada abad XX. Keduanya memiliki ciri khas tersendiri dalam menentukan perkembangan Islam melalui metode Islamisasi adaptif dan modernis. Akhirnya Islam menjadi pranata yang integral di tengah masyarakat Sulawesi Tengah. Kedua figur tersebut juga dikenal sebagai penganut tarekat Syattariyah dan Alawiyyah. Tulisan ini memanfaatkan metode sejarah sebagaimana dijabarakan Kuntowijoyo (2006), bahwa peristiwa sejarah tidak hanya menujukkan sisi periodik satu peristiwa, namun arah dan gerak peristiwa yang dapat mengubah sebuah fenomena atau peristiwa dari satu objek. Sebuah persitiwa historis membutuhkan ilmu bantu untuk membedah setiap sisi dari persitiwa yang telah terjadi di masa lalu. Oleh karena itu, Sartono (1982) berkesimpulan jika narasi sejarah idealnya ditulis dengan memperhatikan penjelasan kausalitas dan determiner dalam satu persitiwa. Akhirnya tulisan ini berkesimpulan suksesnya poros Islamisasi di Sulawesi tidak sekadar kronik sejarah, lebih jauh ia berimplikasi pada historiografi yang optimis dimana pemikiran dan dinamika gerakan Islam di Sulawesi Tengah pada sampai pada abad XX memperkuat posisi serta warisan pemikiran sejarah Islam di Sulawesi Tengah.

Kata Kunci: Pemikiran Islam, Sulawesi Tengah, tarekat, Syattariyah, Alawiyyah 


\section{Pendahuluan}

Era pemikiran dunia Islam di Nusantara mengalami perkembangan signifikan sejak sufisyariat mulai menggeser kedudukan sufi-tauhid yang berkembang sebelumnya (Firdaus, 2018; Haliadi, 2021; Taufani, 2018). Dimulai sejak abad XVII gerakan tarekat diisi kalangan 'elite' agamawan yang merupakan ahli penafsir agama, terutama bidang ilmu kalam, dan teologi yang memperoleh kepercayaan dari penguasa untuk memberikan nasihat atau pengajaran agama setelah penerimaan ajaran Islam (Johns, 1993; Taufani, 2018). Suksesnya pengaruh Islamisasi di Nusantara turut berdampak pada wilayah Sulawesi Tengah. Dalam hal ini, peran utama Dato Karama ${ }^{1}$ menentukan penyebaran Islam dengan metode sufi yang adaptif kepada penduduk setempat. Sedangkan Sayyid Idurs bin Salim Aljufrie di lain pihak melalui media pendidikan dan dakwah (Rasyid, et al., 2018).

Dato Karama (Abdullah Raqie) merupakan ulama Minangkabau yang dipengaruhi oleh Abdul Rauf asSingkili dan Burhanuddin Ulakan (Nurdin \& Maddini, 2018). Kedatangan Dato Karama di Sulawesi Tengah tidak lepas dari proses pelayaran maritim yang signifikan, terutama jejaring niaga rempah Malaka dan Maluku (Nadjamudin, 2016). Para akademisi menyimpulkan kontekstualisasi gerakan sufi sekitar abad XVI hingga XIX mengakar dari konsep jejaring dan relasi niaga, age of commerce, antara TimurBarat serta perkembangan pemikiran Islam (Azra, 2006; Hall \& Reid, 1994). Begitupula dengan peran ulama lainnya, Sayyid Idrus bin Salim Aljufrie yang menjadi suksesor dalam kesuksesan masyarakat Muslim di Sulawesi Tengah yang lebih modernis, reformis, dan puritanisme abad XX (Mahid, et al., 2018). Keduanya merupakan tokoh sentral dalam membahas Islamisasi dan Masyarakat Muslim di Sulawesi Tengah, terutama melalui gerakan sufisyariat dan pendidikan, dengan metode yang adaptif dan reformis.
Konteks di atas menunjukkan jika pengaruh pemikiran Islam yang dibawa para penyebar, terutama kalangan sufi, mampu beradaptasi di tengah masyarakat lokal. Tulisan ini berusaha mendeskripsikan perkembangan Islam tojoh sufi dan tarekat, khususnya Dato Karama dan Sayyid Idrus bin Salim Aljufri, serta dunia pemikiran Islam yang bertahan di Sulawesi Tengah sampai abad XX. Beberapa tulisan mengenai kedua tokoh tersebut yang berusaha menunjukkan adanya poros Islamisasi dari kalangan sufi dengan berbagai pendekatan, teori, dan metode. Beberapa di antaranya, Johns (1993) menunjukkan bahwa salah satu jalur penting dalam pengenalan dan pengembangan Islamisasi yakni kalangan sufi dengan pendekatan sosiologis-politik. Wink (1996) menyoroti perkembangan jejaring niaga yang mendukung perpindahan para pelaku dan penyebar Islam dengan pendekatan ekonomi-politis. Sedangkan Rasyid dan Nurdin (2021) menunjukkan faktor pendukung dari eksistensi sufistik, yakni jejaring niaga dan hubungan perkawinan yang diperkuat dengan pendekatan sejarah. Lebih spesifik, kajian yang dilakukan oleh Haliadi (2021), Madini dan Nurdin (2018), Syawal (2019), serta Azis (2021) mengindikasikan Islamisasi di Sulawesi Tengah berakar sejak kedatangan ulama Sumatera melalui jalur pelayaran. Islamisasi di Sulawesi Tengah mengembangkan pola ajaran agama sebagai solusi atas kondisi masyarakat sebagai wadah pembelajaran, gerakan politik keagamaan; dan solusi atas problematika umat pada masa kini (Howell, 2007; Ridgeon, 2014; Rozehnal, 2016).

Diskursus Islamisasi cukup banyak ditemukan, terutama pada kajian kawasan Nusantara masa lalu yang hampir semua sepakat dipengaruhi Islamisasi yang diperoleh dari berbagai jalur, termasuk para tokoh sufi (Dalimunthe, 2016). Dari Johns (1993), Rosatria (1996), dan Azis (2016) yang merekonstruksi jika wilayah Sumatera menjadi titik 
sentral penerimaan ajaran Islam yang berkembang di Nusantara. Hal tersebut diperkuat melalui temuan-temuan yang menunjukkan relasi politik serta pembentukan komunitas Muslim di kemudian hari. Pendekatan sosial-politis dalam kajian sejarah Islam cukup banyak ditemukan yang memposisikan kalangan sufi sebagai aktor pendukung dalam keberhasilan Islamisasi dari para penguasa lokal. Di sisi lain, kekuatan politik tidak hanya sebagai faktor utama dalam kesuksesan Islamisasi di Nusantara, namun relasi dan jejaring pelayaran juga menjadi kekuatan lain dalam perkembangan Islam (Hall \& Reid, 1994). Kajian yang spesifik dalam membahas Islamisasi di Sulawesi Tengah dilakukan Kruyt (1938) yang menjabarkan jika Islam diterima oleh penduduk setempat karena pengaruh Sumatera sejak abad XVII. Pembacaan tersebut tidak lepas dari pengumpulan informasi mengenai masyarakat Sulawesi Tengah ketika ditunjuk sebagai misionaris di wilayah Sulawesi TengahakhirabadXIX (Churchill, Adriani, \& Kruijt, 1915). Meski tergolong sekumpulan laporan perjalanan pemerintah kolonial, deskripsi tersebut memberikan informasi jika Islam telah diperkenalkan sejak abad XVII. Nurdin dan Maddini (2018) menyerbutkan jika Islamisasi di kawasan Sulawesi Tengah ditentukan keberadaan ulama Minangkabau melalui jejaring niaga yang sampai ke Sulawesi. Disebutkan Dato Karama menjadi tokoh sentral dalam pengenalan ajaran Islam di Sulawesi Tengah. Pendekatan sosilogis digunakan dalam kajian tersebut yang menunjukkan dampak dari Islamisasi yang dilakukan oleh Dato Karama pada abad XVII.

Dalam hal itu, pengaruh pemikiran dari Abdul Rauf As-Singkili dan Burhanuddin Ulakan terjelma dalam proses penyebaran Islam yang dilakukan oleh Dato Karama di Sulawesi Tengah (Syawal, 2019). Pandangan ini tidak lepas dari periodisasi yang hampir bersamaan dengan warisan pemikiran dan pengaruh as-Singkili dan Burhanuddin Ulakan di tengah masyarakat Muslim Minangkabau. Disebutkan pula, para ulama yang berpengaruh di Sulawesi Tengah memiliki karakter berbeda. Islamisasi yang berkembang dipengaruhi oleh pemikiran 'mitologis' penduduk lokal dalam memandang Islam. Sebutan dari 'Karama' yang berasal dari kata Keramat memperkuat kondisi tersebut, sedangkan kata 'Dato' sendiri disematkan karena pembawanya berasal dari daratan Melayu, Sumatera (Haliadi, 2021).

Tidak hanya, Dato Karama, tokoh lain seperti Sayyid Idrus bin Salim Aljufri menjadi ulama lainnya yang memperkuat posisi Islam di Sulawesi Tengah. Meskipun memiliki jarak periodisasi yang jauh berbeda dari pendahulunya, Sayyid Idrus bin Salim Aljufri merupakan tokoh Islam yang dianggap berperan penting dalam mempertahankan eksistensi keislaman di Sulawesi Tengah abad XX. Disebutkan kedatangan Sayyid Idrus bin Salim Aljufri memperkuat pengaruh Islam di Sulawesi Tengah melalui jalur pendidikan (Mahid et al., 2018). Tokoh ini tidak hanya dikenal sebagai pendidik namun juga penganut tarekat. Keterikatan nasab Sayyid Idrus bin Salim Aljufri memiliki warisan pemikiran genealogi tarikat Alawiyyah (Jumat, 2012) justru menggambarkan peran para tokohtokoh Islam dari abad XVII sampai abad XX yang berpengaruh tidak hanya di Palu, namun hampir di seluruh wilayah Sulawesi Tengah (Haliadi, 2021).

Sayyid Idrus bin Salim Aljufri merupakan tokoh modernis, sekaligus reformis dalam pemikiran Islam di Sulawesi Tengah (Asy'ari \& Bahdar, 2019; Rasyid et al., 2018). Lebih spesifik keberadaan sosok ini memperkuat peranan kalangan 'Arab' dalam mempertahankan identitas keislaman masyarakat di Sulawesi Tengah. Sehingga kajian ini menambah wacana dan khazanah keislaman di Sulawesi Tengah, utamanya kajian peradaban dan pemikiran Islam, khususnya gerakan tarekat Syattariyah dan Alawiyyah di Nusantara. Penulis 
melihat masih terdapat celah dalam menyajikan informasi mengenai gerakan tarekat dan pemikiran Islam serta relasi perkembangan Islam di Sulawesi Tengah. Isu yang penulis sajikan dalam tulisan ini di antaranya bagaimana pengaruh proses dan poros Islamisasi di Sulawesi Tengah? Seperti apa peran Dato Karama dan Sayyid Idrus bin Salim Aljufrie dalam mengembangkan ajaran Islam dan tarekat di Sulawesi Tengah? Bagaimana perkembangan pemikiran Islam di Sulawesi Tengah melalui gerakan Tarekat Syattariyah dan Alawiyyah pada abad XVII hingga abad XX?

\section{Hasil dan Pembahasan}

\section{Diskursus Islamisasi di Sulawesi Tengah}

Perkembangan Islam di Nusantara tidak lepas dari poros dakwah serta pengajaran sIslam di masa lalu, terutama gerakan sufistik dan tarekat. Dalam hal ini peran kelompok sufi sebagai lambang dari peradaban sastra dan titik awal pemikiran Islam yang lebih aplikatif dan fungsional (Johns, 1961). Mereka merupakan katalisator yang transformatif dalam penyebaran Islam di Nusantara. Para ulama Nusantara terhubung secara kontinu ke pusat perkembangan Islam di Timur Tengah dengan kondisi lokal yang terjadi di masyarakat. Pendek kata, proses Islamisasi cukup kompleks untuk diposisikan dalam gambaran sufisme yang berpengaruh di masa awal (Azra, 2002). Nuruddin ar-Raniri dan Abdul Rauf as-Singkili dianggap sebagai aktor yang menanggapi doktrin wahdatul wujud dengan doktrin wahdah al-syuhud yang cukup moderat (Kharlie, 2006). Meski demikian, posisi Abdul Rauf as-Singkili dalam menyebarkan Islam tergolong sebagai ulama yang representatif dan berpandangan moderat.

Dalam upaya menyebarkan Islam di Nusantara kalangan sufi merupakan kelompok urban yang menjadi fenomena tersendiri dalam persebaran ajaran Islam (Johns, 1961,1995).Persoalan Islamisasi jalur sufistik juga ditemukan dalam literatur terdahulu, termasuk dalam naskah Sulalah alSalatin yang disunting oleh Abdullah bin Abdulkadir al-Munsyi dan dianotasi oleh Situmorang dan Teew (Azis, 2016) di mana para tokoh sufi memainkan peran penting dalam pengenalan ajaran Islam dan penyebaran Islam. Di sini kalangan sufi merupakan cendikiawan sekaligus tokoh politis dalam sistem hirearki lokal di masa lalu, terutama dalam proses meyebarkan dan mengajarkan Islam (Azra \& Fathurrahman, 2002). Dalam Turjumun al-Mustafid tampak cara berfikir as-Singkili sebagai ulama yang tidak hanya memahami tekstual semata, melainkan juga kontekstual (Abdullah \& Masduki, 2017). Selain itu, ulama kharismatik ini juga merupakan sosok moderat sebagaimana dibaca dalam Mir'at atTullab (Salleh et al., 2019).

Dua kitab di atas menunjukkan warisan pemikiran as-Singkili, khususnya yang diajarkan pada murid-muridnya (Fang, 2011). As-Singkili menyiratkan ajarannya kepada muridnya untuk menyucikan diri agar dapat menyatu dengan Sang Khalik sebagaimana yang tertuang dalam Kifayat Muhtajin (Rinkes, 1909). Dalam Dakaik al-Huruf asSingkili menyatakan Sang Khalik tidak sama dengan makhluk atau alam. Makhluk harus bertauhid melalui empat martabat yakni tauhid uluhiyat, af'al, tauhid sifat dan tauhid zat (Johns, 1995). Pandangan tersebut juga diamalkan oleh Burhanuddin Ulakan, murid as-Singkili, yang dikenal sebagai ulama penyebar Islam setelah as-Singkili (Aryanti, 2014). Selain Burhanuddin Ulakan, tokoh lain seperti Abdullah Raqie notabene murid as-Singkili yang menjadi penyebar Islam di Sulawesi Tengah pada abad XVII (Haliadi dan Syamsuri, 2016; Nurdin 2018). Jejaring ini bersambung melalui gerakan tarekat Syattariyah yang berkembang abad XVII melalui para mursyid tarekat, terutama hubungan guru-murid antara as-Singkili dan Burhanuddin Ulakan serta Abdullah Raqie. 
Jejaring tarekat ini merupakan sebagai sebuah organisme yang tidak terputus hingga awal abad XIX. Lebih lanjut, peran Burhanuddin Ulakan dalam jejajring ulama Melayu-Indonesia abad XVIII. Karir Burhanuddin Ulakan beserta perjalanannya mempengaruhi banyak ulama di masanya hingga periode selanjutnya (Azra, 2013). Sedangkan Abdullah Raqie merupakan satu sosok di antara banyak ulama yang memiliki hubungan dengan Burhanuddin Ulakan, meskipun masih minim ditemukan kajian-kajian yang membahas hubungan keduanya. Kesinambungan antara pemikiran Burhanuddin Ulakan dengan Abdullah Raqie tampak melalui cara pandang dan pemahaman keduanya terhadap rekonsiliasi pemahaman syri'ah dan tasawuf dimana pandangan tersebut dipraktikkan melalui tiga pilar utama yakni Tuhan dan alam. Insan Kamil, dan jalan kepada Tuhan. Abdullah Raqie mengembangkan pemikiran ini melalui metode dakwah moderat di Sulawesi Tengah yang tidak hanya melalui pendekatan syariattasawuf namun juga budaya masyarakat setempat. Akhirnya masyarakat setempat menerima dakwah Abdullah Raqie untuk memeluk agama Islam. Para sufi yang menghidupkan tarekat dimaknai juga sebagai metode untuk menekan nafsu duniawi dengan meninggalkan berbagai macam yang mendatangkan mudhorat atau hal yang sia-sia. Esensi dari pengajaran sufi adalah spritualitas, moral, ketenangan, ketersingkapan, hakikat, dan intuisi langsung terhadap pensucian diri dan batin, kedamaian hati, dan memaknai hakikat manusia untuk menuju kepada sang Khalik.

Kondisi Nusantara tentunya berdampak di Sulawesi Tengah dimana konsepsi 'Islam Politik' dan 'Politik Islam' telah berkembang sejak abad XVII melalui dominasi ekonomi dan hegemoni politik perdagangan. Kalangan sufi menjadi kelompok urban yang harus menghadapi situasi dan kondisi masyarakat yang dinamis. Hal di atas berdampak pada perkembangan Islam di Sulawesi Tengah di mana tokoh-tokoh yang menjadi aktor utama dalam proses penyebaran Islam tidak lepas dari wilayah episentrum peradaban Islam di Nusantara, yakni Melayu dan Sumatera. Keberadaan Islam di beberapa wilayah seperti Sulawesi memiliki relasi dengan daratan Sumatera melalui tiga ulama Sumatera yang datang ke Kesultanan Makassar sejak awal abad XVII. ${ }^{2}$ relasi tersebut dimungkinkan melalui proses jejaring niaga maritim yang berlangsung dengan beberapa kawasan persinggahan sebelum tiba di Maluku (Reid, 2011).

Islamisasi di daratan Sulawesi dikatakan berawal pada abad XVII. Pada 1603 atau 1605 pengaruh tersebut berpijak pada kondisi politik yang terjadi di kawasan tersebut. Namun jika menarik jauh sedikit ke belakang, beberapa jalur 'samar' dalam proses Islamisasi bisa saja terjadi. Tiga Muballigh Sumatera di Makassar, Dato dari Bandang, Dato ri Tiro, dan Dato ri Pattimang sebagai tokoh penyebar Islam di daratan tersebut. Sedangkan dua tokoh lain seperti Dato Karama dan Dato Mangadji menjadi penyebar Islam di daratan Sulawesi Tengah pada abad XVII. Selain jalur Sumatera, sumber lain menyebutkan bahwa pengaruh Mindanao telah berkembang di daratan Sulawesi bagian utara (de Graaf, 2001).

Islamisasi di Nusantara tidak lepas dari proses transformasi dan representasi dari proses perkembangan Islam (Laffan, 2015). Poros Islamisasi membentuk poros keilmuan pada wilayah yang menerima pengaruh Islam. Islamisasi Dato Karama dan Dato Mangadji di Sulawesi Tengah memperkuat jejaring Sumatera-Sulawesi pada abad XVII. Proses tersebut tidak lepas dari karakteristik persebaran Islam di Nusantara dimana orangorang berpengaruh menyebarkan pengaruhnya di tengah masyarakat. Meski pada beberapa kasus, proses Islamisasi tidak hanya disebabkan oleh pengaruh politis namun sosial. Beberapa akademisi sulit untuk melepaskan pengaruh politis dalam 
proses Islamisasi. Dalam hal ini beberapa kekuatan lokal terlebih dahulu menerima ajaran Islam lantas menyebarkan kepada penduduk setempat (Tjandrasasmita, 1975).

Bukti kuat dari berhasilnya proses Islamisasi di Sulawesi Tengah, bahwa Sultan Muhammad Tahir Wadzir al-Adhim Abdurrahman atau Madika Eato di Buol memiliki relasi dengan Ternate. Selanjutnya, Syekh Abdul Wahid bin Syarif Sulaiman yang berasal dari daratan Patani, dan mengislamkan Raja Buton, Wolio, pada 1564 M (Malek, 2006) yang kemungkinan pernah mengunjungi Banggai sebelum ke Buton. Sebagian berpendapat bawah wilayah yang mengalami proses Islamisasi pertama kali di Sulawesi Tengah adalah Lembah Palu, Paloe Valley (Kaudern, 1925). Sedangkan sebagain lain menyebutkan Islamisasi Sulawesi Tengah berasal dari Kesultanan Luwu, dan Kerajaan Sigi dan Tojo (Churchill et al., 1915). Daratan lain yang menerima pengaruh Islam adalah Bungku melalui seorang muballigh Bernama Syekh Maulana atau Datu Maulana Bajo Johar yang diperkirakan berasal dari Ternate. Lain halnya Tojo Una-Una, tidak hanya pembawa Islam dari Ternate, orang-orang dari Bugis, Mandar, dan Makassar juga mempengaruhi perkembangan ajaran Islam. Secara umum, Islamisasi di Sulawesi Tengah memiliki beberapa periodisasi yang berbeda untuk setiap daerah, namun satu hal yang pasti pengaruh penyebar Islam dari daratan Melayu, Ternate, Bugis, Mandar, dan Makassar menandai keberadaan Islam di wilayah tersebut.

Media atau saluran tasawuf menjadi media alternatif dan terbukti efektif untuk menyebarkan Islam. Alasanya gerakan ini mudah mengakomodasi para penduduk pribumi. Di sisi lain, karya tulis dan beberapa naskah-naskah lokal banyak mengisahkan jika Islamisasi melalui jalur Tasawuf cukup berhasil untuk penduduk lokal yang tinggal jauh dari pusat pemerintahan. Salah satu bukti konkrit yakni keberadaan Dato Karama dan Dato Mangadji di Sulawesi Tengah yang berhasil mengajarkan Islam kepada penduduk lokal (Mamar, et al., 1984). Banggai dan Buol kemudian dikenal sebagai salah satu wilayah yang pertama kali menerima ajaran Islam di daratan Sulawesi Tengah melalui peranperan penting para pembawa Islam (Kutoyo dan Sumardi, 1986, 1987). Namun dari diskursus di atas dapat ditarik beberapa kesimpulan yakni jejaring ulama Sumatera-Sulawesi yang menjadi aktor utama dalam proses Islamisasi yang terjadi pada masa awal sekitar abad XVII hingga abad XIX. Selanjutnya, jejaring tarekat yang menghubungkan antara Dato Karama, dan Abdul Rauf as-Singkili, Syekh Burhanuddin Ulakan, dan Abdullah Raqie (Dato Karama) yang menganut ajaran Tarekat Syattariyah (Bruinessen, 1995).

\section{Jejaring Tarekat di Sulawesi Tengah: Akar Gerakan dan Pemikiran Islam Abad XIX}

Jejaring tarekat berkembang cukup pesat pasca banyaknya masyarakat Muslim yang kembali ke Nusantara setelah melakukan perjalanan haji. Mereka yang berhaji tidak hanya sekadar menunaikan ibadah haji namun sekaligus memperdalam ilmu agama. Banyak di antara mereka membangun relasi guru-murid hingga dikenal sebagai kelompok Ashabul Jawiyyin dan juga sebagai kalangan penganut sufi dan tarekat (Azra, 2013; Laffan, 2015). Mereka berperan sebagai transmitor pemikiran dari pusat pemikiran dan peradaban Islam di Makkah dan Madinah ke Nusantara, bahkan kecenderungan pemikiran tersebut berdampak hingga abad XX. Salah satu kecenderungan pemikiran Islam yang paling berpengaruh adalah orientasi syariah-sufistik dengan proses yang mempertimbangkan konteks masyarakat yang masih banyak terpengaruh dengan pemikiran animis dan dinamis. Sehingga jalan tengah yang muncul adalah gerakan tarekat 
sebagai proses 'sinkreatisme Islam', walau pada masa selanjutnya banyak menimbulkan justifikasi bid'ah, takhayyul, dan khurafat (Bruinessen, 1995; Huda, 2007).

Pada posisi tersebut, kalangan sufi berada pada lapisan 'elite' politik dan agamawan di tengah masyarakat dengan peran memadukan budaya lokal dan ajaran Islam, atau dikenal dengan istilah rekonsiliasi syariat-tasawuf. Bahkan peran lain memperkuat posisi penguasa dalam menjalankan setiap kebiajakan yang bersinggungan dengan keagamaan. Penerapan tersebut berdasarkan pada konteks moral-sosial yang masih bersinggungan dengan pemahaman animis dan dinamis. Seringkali kalangan elite politik meminta dukungan kalangan agamawan untuk merespon dominasi kolonial pada abad XIX sebagai usaha melawan intriks politik-agama Hindia Belanda. Tujuan utamanya mempertahankan posisi dan pengarih terhadap penduduk, bahkan sebagai gerakan resistensi terhadap kolonisasi (Geertz, 1982).

Di Sulawesi Tengah, gerakan tersebut terjadi melalui salah seorang tokoh mursyid Tarekat Syattariyah bernama Syarif Mansur yang berelasi dengan tiga ulama mursyid tarekat Syattariyah di Paleleh dan Attinggola (Riedel, 1876). Mereka melancarkan perlawanan terhadap pemerintah Belanda di Manado pada 1875 (Lapian, 2011). Respon tersebut mengindikasikan xenophobia di tengah masyarakat Muslim Nusantara akibat dari fanatisme agama untuk tetap melawan kelompok 'kafir' yang merusak tatanan sosial dan ekonomi masyarakat (Suminto, 1996). Gerakan kebangkitan tersebut merupakan wadah pergerakan masyarakat Muslim sebagai organisme dan kesatuan. Oleh karena itu, mereka membentuk kontak dan relasi ulama dan masyarakat adalah bukti untuk mempertahankan eksistensi Islam di mana Ulama sebagai bagian atau bahkan aktor penggerak dalam setiap pergolakan melawan kolonisasi Belanda (Azra, 2001). Meskipun kurang catatan yang menunjukkan pengaruh tarekat dalam gerakan perlawanan abad XIX, namun hal ini mengindikasikan umat Muslim merespon gerakan dominasi dan kolonisasi Eropa. Sebagaimana disebutkan Sartono (1966), bahwa gerakan tarekat tidak hanya sebagai kelompok yang berpengaruh terhadap kebangkitan peran dan pengaruh Islam di abad XIX, namun juga daya tarik tarekat mampu memperkuat posisi politik para penguasa lokal dalam membendung hegemoni kolonialisme.

Gerakan lain yang muncul dalam proses transisi Nusantara pada akhir abad XIX menuju abad XX adalah pengaruh dari gerakan tarekat Alawiyyah. Gerakan ini pada awalnya sebuah gerakan yang 'terbatas' melalui para ulama-ulama yang langsung dari Hadhramaut. Tarekat ini disandarkan pada Imam Muhammad bin Ali Ba 'Alawi yang bergelar Faqih Muqaddam (Shihab, 2009) dan para ulama Hadhramaut yang berada di Nusantara (Ibrahim, 2001). Tarekat Alawiyyah dikembangkan Sayyid Idrus bin Salim al-Jufri, Idrus bin Salim bin 'Alawi bin Saggaf bin Muhammad bin Idrus bin Salim Husain bin Abdillah bin Shaekhan bin 'Alawi bin Bakar (Aljufri) bin Muhammad bin 'Ali bin Muhammad bin Ahmad bin Muhammad bin 'Ali bin Muhammad bin 'Ali bin Muhammad bin 'Ali bin 'Alawi bin Muhammad bin 'Alawi bin Ubaidillah bin Ahmad bin Isa bin Muhammad bin 'Ali (al-Uraidhi) Ja'far (al-Shadiq) bin Muhammad al-Baqir bin Zain al-Abidin 'Ali bin Huasin (as-Sibti) bin 'Ali bin Abi Thalib yang terpengaruh oleh gerakan 'Alawi sejak masa mudanya (Jumat, 2012). Sayyid Idrus bin Salim Aljufri mampu memiliki pengaruh besar di Sulawesi Tengah membangun jejaring Alawiyyah di Sulawesi Tengah. Misi dakwah dan pendidikan agama yang dibawa oleh Sayyid Idrus bin Salim Aljufri mampu menjadi salah satu faktor utama dalam melakukan perlawanan terhadap kolonialisme dan imprealisme serta membawa pengaruh revivalisasi pemikiran keislaman di wilayah tersebut. 
Neo-Sufisme: Dinamika Syattariyah dan

Alawiyyah di Sulawesi Tengah Abad XX

\section{Dato Karama}

Telah dibahas secara sekilas mengenai kedatangan Dato Karama ke Sulawesi Tengah pada abad XVII atau diperkirakan pada 1606 bersama dengan keluarganya (Kotilainen, 1992) di masa kekuasaan Raja Kaboena, pangeran Pue Nggari, di Palu (Sadi \& Syamsuri, 2016). Peran utama dari Dato Karama yakni mampu melakukan penyebaran Islam dengan metode yang adaptif di tengah masyarakat lokal. Kedatangan Dato Karama diawali dari pelayarannya menuju Maluku yang kemudian tiba di Karampe, Kaili, Parigi, Donggala, Kalawi, Parigi dan Ampana dengan membawa beberapa alat musik. Datu Karama kemudian meninggal di Kampung Lere dalam kompleks pemakaman 'Dayo Dato Karama' (Abdullah, 1975).

Dato Karama terpengaruh pemikiran Madzhab Imam Syafi'i, Madzhab Abu Hasan al-Asy'ari serta Abu Mansur al-Maturidi, serta ulama Nusantara Abdul Rauf as-Singkil (Ali, 2014), dan Burhanuddin Ulakan sebagai tokoh Tarekat Syattariyah (Suryadi, 2004). Dato Karama dikenal sebagai ulama yang tumbuh dan besar di daerah Minangkabau, sehingga proses pengenalan dan pembelajarannya terhadap Islam tergolong kuat. Tokoh ini merupakan ulama dari Sumatera dan berperan besar dalam proses pengenalan ajaran Islam di Sulawesi Tengah (Churchill et al., 1915). Kedatangannya yang berasal dari Sumatera diperkuat melalui bawaan Dato Karama ketika tiba di Palu berupa kakula, jijiri, dan bendera kuning (Anto, 2015). Selain itu, kedatangannya bersama istrinya, Ince Jille, Ince Saharibanong (ipar), dan anaknya Ince Dangko beserta 50 orang rombongannya membawa bendera kuning, panji, puade, jijiri, bulo, gong, dan kakula (kolintang) (Sadi \& Syamsuri, 2016: 8; Mahid et al., 2009). Di sini terlihat jika kebudayaan dan kesenian dari Minangkabau dibawa oleh Dato Karama untuk menyebarluaskan Islam.

Hal ini diperkuat dari gelarnya, 'Karama' yang berasal dari kata 'karamah' dan 'kekuatan di luar nalar' yang berdampak pada penokohan dan mitos yang melingkupi dirinya. Di Sulawesi Tengah sosok Dato Karama tidak hanya terkait kondisi politis dan agama yang berkembang kala itu, namun juga faktor sosial yang bertujuan mengajarkan Islam (Anto, 2015; Kruyt, 1938; Mahid, 2009). Di sisi lain, dia juga melakukan pendekatan kepada penduduk lokal dengan mengajarkan arti berbusana sebab kebanyakan penduduk lokal yang ditemuinya masih menutupi badannya dengan kain kulit kayu (Sadi \& Syamsuri, 2016). Hal ini mengingatkan peran para sufi sebagai tokoh sentral tidak hanya sebagai pembawa Islam semata, melainkan sebagai agent of change yang mampu menyajikan ajaran Islam dengan gaya dan kemasan yang menarik bagi penduduk pribumi. Mereka menekankan kesesuaian yang bergerak terus, dibandingkan dengan memaksakan Islam dengan cara kekerasan (Johns, 1961). Sedangkan di Gorontalo, telah jelas adat dan kebiasaan dari penduduk setempat mengikuti sara', syariat Islam, yang berlaku. Dampaknya, perkembangan tersebut menyebar ke beberapa kawasan sekitar, termasuk di Buol, yang meyakni ajaran Islam dan kebudayaan yang berkembang setelahnya.

\section{Sayyid Idrus bin Salim Aljufrie}

Tidak hanya Dato Karama, tokoh lain yang menghidupkan kembali pemikiran Islam di Sulawesi Tengah adalah Sayyid Idrus bin Salim Aljufrie. Beberapa akademis mengenalnya sebagai tokoh pembaharu pendidikan Islam di awal abad XX, khususnya di Sulawesi Tengah yang membawa gerakan pemikiran Islam modern. Namun beberapa aktivitasnya seringkali berhubungan dengan gerakan Tarekat Alawiyyah yang diperolehnya dari latar belakang kehidupannya selama menuntut ilmu 
di Hadhramaut, Tarim. Dalam silsilahnya, Sayyid Idrus bin Salim Aljufrie memiliki relasi langsung dengan faqih Muqaddam yang menghidupkan Tarekat Alawiyyah yang diperoleh dari ayahnya, Salim al-Jufri bin Alawy adalah salah seorang penganut, dan mursyid tarekat alawiyyah, yang cukup dikenal sebagai ulama berpengaruh. Selain itu, gurunya seperti Sayyid Muksin bin Alwy Assegaf, Abdurrahman bin Ali bin Umar bin Assegaf, Muhammad bin Ibrahim Balfaqih, Abdullah bin Husain Al-Bahr, dan Idrus bin Umar al-Habsy merupakan pengamal tarekat Alawiyyah (Ali, 2010).

Dakwah Sayyid Idrus bin Salim Aljufrie dilakukan sejak 1922 hingga menetap di Palu sampai wafatnya pada 1969 (Jumat, 2012) dengan lembaga miliknya, Al-Khairaat. Pendirian lembaga ini memperoleh izin dari controleur Proschot Hindia Belanda di Palu pada 1930 (Kadir, 2013; Kambay, 1991). Aljufrie mengajar Islam secara tekstual dan kontekstual melalui metode adaptasi dan asimilasi ajaran Islam dengan kehidupan masyarakat setempat. Bahkan ulama ini melakukan revivalisasi dan pembaruan Islam ketika melihat kondisi masyarakat muslim yang masih banyak percaya terhadap hal mistik, tradisional dan sinkretisme.

Dalampenelusuranlapangan, penulismenemukan beberapa hal yang berkaitan dengan Sayyid Idrus bin Salim Aljufrie, terutama di Kabupaten Buol, dan Kabupaten Tojo Una-Una, Provinsi Gorontalo, dan Sulawesi Utara. Beberapa informan menyampaikan peran Sayyid Idrus bin Salim Aljufrie tidak hanya dalam dunia pendidikan formal, namun juga dalam pengembangan ajaran Islam secara informal, seperti diungkapkan Lasawedi (2020): ${ }^{3}$

Sayyid Idrus bin Salim Aljufrie atau Guru Tua tidak hanya mengajarkan Islam melalui lembaga Alkhairat, namun juga melalui berbagai media informal seperti tarekat dan pengajian rutinan di masjid-masjid kampung pada masa itu. Menurutnya, Sayyid Idrus bin Salim Aljufrie merupakan salah satu penganut tarekat Alawiyyah yang berkembang di Sulawesi Tengah sampai sekarang ini.

Sayyid Idrus bin Salim Aljufrie berkontribusi langsung dalam perkembangan Islam di Sulawesi Tengah pada abad XX. Melalui pendidikan dunia intelektual mampu bersaing dan melawan penjajahan dengan cara yang lebih elegan (Jumat, 2012). Selain itu, Sayyid Idrus bin salim Aljufrie tidak pernah memberikan batasan bagi muridmuridnya untuk mempelajari ilmu-ilmu duniawi. Pada akhirnya, kondisi umat Islam sekitar abad XIX dan XX di Sulawesi tengah seperti dalam pandangan Laffan memasuki Pergeseran dan Perpisahan dimana ditandai dengan gerakan kebangkitan masyarakat Muslim Nusantara. Kekuatan Umat Islam berjalan progresif di mana para pembaharupembaharu dari kalangan cendikiawan Muslim Nusantara banyak terlibat dalam berbagai gerakan perlawanan terhadap kolonialisasi. Tidak hanya gerakan politik, namun pendidikan dan tarekat juga menjadi bagian yang membuat pemerintah kolonial khawatir. Langkah tersebut mengubah wajah gerakan Muslim di Nusantara pada pertengahan abad XX sebagai kalangan muslim yang reformis, modernis, dan juga konservatif atas pemikiran umat Islam. Tindakan ini tidak lepas dari bibit pemikiran keislaman yang selalu terbuka atas perekembangan yang terjadi. Mereka mengikuti arus pemikiran yang modern, begitupula dengan cara pandang yang terbuka terhadap dunia pendidikan Islam (Laffan, 2015).

\section{Syattariyah dan Alawiyyah: Jejaring dan}

\section{Dinamika Gerakan Islam Modern di Sulawesi}

\section{Tengah}

Kecenderungan pemikiran ulama muslim Nusantara pada abad XIX lebih banyak dipengaruhi oleh praktik dan rekonsiliasi antara syariah dan tasawuf yang berdampak pada abad XX. 
Kecenderungan salafisme yang berdampak pada rekonsiliasiarah pemikiranyang reformis, revivialis, modernis, dan puritanis dari kalangan cendikiawan Muslim generasi akhir abad XIX dan awal abad XX (Laffan, 2015). Bibit pemikiran tersebut berakar sejak abad XVII yang mayoritas belajar langsung ke pusat keilmuan serta dan peradaban Islam, Mekkah dan Madinah. Kondisi masyarakat yang harus menghadapi kolonisasi dan dominasi Eropa membuat cendikiawan Muslim Nusantara memilih 'jalan tengah' untuk berusaha mencari jalan keluar. Akibatnya pada abad XIX dan XX banyak ulama yang tidak hanya sebagai figur agama namun juga politik di tengah masyarakat Nusantara. Seperti di Batavia di mana Sayyid Usman tidak hanya dikenal sebagai ulama. Beliau juga dipercaya pemerintah kolonial sebagai penasehat masyarakat Muslim, khusus Arab di Nusantara, sehingga beberapa kebijakan darinya berimplikasi pada kehidupan masyarakat muslim abad XIX dan XX (Bruinessen, 1995).

Orientasi gerakan umat Islam bermuara pada gerakan politik dan orientasi pendidikan yang bertujuan untuk mengimbangi dominasi Eropa di Nusantara. Pada awal abad XX respon umat Islam terhadap dominasi Eropa melibatkan para cendikia dan pemuka agama. Jaringan patronase kembali dimunculkan pada dua gerakan yang baru berkembang di Nusantara. Jaringan politik banyak berpengaruh pada pemiliran kalangan terpelajar seperti Muhammad Abduh dan Rasyid Rida yang mengarahkan pada gerakan Islam puritanis. Sedangkan kelompok pemikiran Islam lebih banyak mengelaborasikan pemikiran modernis dan gagasan pemikiran sufisme di masa lalu. Akibatnya, muncul gerakan transimisi reformis di Nusantara dan Melayu yang mersepon dengan gerakan yang lebih massif.

Terdapat cukup banyak bukti yang mengindikasikan munculnya intriks untuk melawan pemerintah kolonial ketika tokoh-tokoh Muslim
Nusantara kembali dari Mekkah atau bahkan terpengaruh dengan pemikiran-pemikiran dari kalangan modernis di Timur Tengah (Steenbrink, 2017). Seperti pada penggunaan gelar 'haji' yang berdampak pada rasa percaya diri untuk melakukan perlawanan terhadap tindakan kesewenangwenangan pemerintah kolonial yang merugikan umat Islam, sehingga terjadi berbagai perlawanan dari tingkal nasional ke lokal ataupun sebaliknya (Martin, 2002). ${ }^{4}$

Di Sulawesi Tengah gerakan kebangkitan masyarakat Muslim melalui jejaring tarekat terlihat dari aktivitas penganut tarekat Syattariyah di akhir abad XIX. Syarif Mansur, mursyid tarekat Syattariyah, menjadi aktor sentral gerakan reformis pada dekade 1850-an. Selain itu, gerakan ini menghimpun umat Muslim lainnya termasuk di Paleleh dan Attingola (Riedel, 1875). Gerakan perlawanan ini ditujukan kepada pemerintah Hindia Belanda yang berkedudukan di Manado, walau pada akhirnya gerakan ini mampu diredam oleh pemerintah kolonial.

Gerakan lain, Arsyad Thawil di awal abad XX turut mempengaruhi gerakan kebangkitan Islam lain di Semenanjung Laut Sulawesi. Pengaruh Syattariyah sampai abad XX masih bertahan hingga di kawasan Manado. Syattariyah juga berkembang pesat di Manado melalui warisan pemikiran Kyai Modjo dan K. H. Arsyad Thawil. Kyai Modjo ${ }^{5}$ dikenal sebagai mursyid tarekat syattariyah yang menghidupkan dan melestarikannya selama di daerah pengasingannya, Tondano. Begitupula dengan K. H. Arsyad Thawil menjadi pelanjutnya, meskipun K. H. Arsyad Thawil bukan sebagai murid Kyai Modjo, namun keduanya memiliki relasi guru murid hingga ke Abdul Rauf as-Singkili (Azra, 2002). Posisi Arsyad Thawil dalam Raad Agama berimplikasi pada kebangkitan umat Islam dalam tingkat lokal dan nasional. Pijper menyebut adanya ketakutan dari pemerintah Kolonial pada masa itu 
dimana Arsyad Thawil dikenal dengan pengaruh reformis dari dunia pendidikan dan pemikiran tarekat (Laffan, 2015).

Warisan pemikiran tarekat Syattariyah di Sulawesi Tengah memiliki relasi utama kepada Abdul Rauf As-Singkili dan Dato Karama serta beberapa mursyid tarekat di kawasan lain di Sulawesi Tengah. Keberlangsungan tarekat Syattariyah di Sulawesi Tengah terus bertahan melalui para ulama yang datang. Di antara Abdullah Raqie, terdapat Syarif Mansur, dan serta Imam Lapeo yang menjadi penghubung dan pelestari tarekat Syattariyah sampai abadXX. Akibatnya, pemikiran tersebutterus tumbuh dan bertahan serta direpresentasikan Umat Muslim di Sulawesi Tengah. Meski menjadi gerakan lokal, namun gerakan pemikiran tersebut terhubung dengan beberapa tokoh tarekat di Sumatera dan Jawa sampai abad XX. Gerakan tersebut merupakan poros proses transformasi Islam menjelang masa modern. Beberapa wilayah seperti Besusu, Siranindi, Lere, dan Kampoe Baroe menghidupkan gerakan ini melalui surau atau langgar, serta transformasi ilmu, termasuk tasawuf, dengan cara memadukan syariah, akidah, dan tasawuf (Kruyt, 1938). Praktik tersebut bertujuan menerapkan praktik amali yang tidak bertentangan dengan esensi iman, dan mampu adaptif dengan kebutuhan masyarakat setempat. Akibatnya, muncul kelompok-kelompok muslim moderat dan akomodatif terhadap praktik keagamaan serta menghadirkan tokoh-tokoh pemikir modernis dalam peradaban Islam di Sulawesi Tengah. Modernisasi yang terjadi adalah respon positif atas praktik politik-keagamaan yang diterapkan oleh pemerintah kolonial terhadap Umat Islam. Di sisi lain, tarekat ini secara tidak langsung menjadi satu wadah bagi masyarakat untuk melestarikan pemikiran-pemikiran Islam untuk mempertahankan eksistensi umat Muslim di Sulawesi Tengah.

Tarekat Alawiyyah menjadi gerakat lain yang juga berpengaruh besar terhadap pemikiran Umat Muslim di Sulawesi Tengah. Sayyid Idurs bin Salim Aljufrie dikenal sebagai sosok sentral membangun dan membentuk wadah bagi umat Islam melalui jaringan ulama Arab di Jawa, Kalimantan, dan Sulawesi Tengah. Gerakannya yang modernis dan transformatif sejalan dengan perkembangan pendidikan Islam dianggap berdampak positif. Beliau dikenal sebagai ulama kharismatik yang berperan besar terhadap dunia pendidikan Islam. Al-Khairaat menghidupkan jejaring pemikiran Sayyid Idrus bin Salim Aljufrie dengan ulama yang mengajar di Makkah, terutama terhadap faqih Muqaddam. Gaya berifikirnya banyak dipengaruhi oleh al-Ghazali, al-Haitami, dan Syafi'i sebagai dasar utama mendirikan dan mengajar di Al-Khairaat (Jumat, 2012).

Melalui tarekat Alawiyyah, Sayyid Idrus bin Salim Aljufrie menghidupkan praktik agama yang modernis dan revivalis. Baginya, pemikiran modernis mampu menjadi satu senjata bagi umat Islam untuk melawan pemerintah kolonial dalam berbagai kebijakan. Pemikiran politiknya yang berusaha melawan imprealisasi Eropa berimplikasi ke Nusantara setelah kedatangannya ke Palu. Beliau pernah menjadi Mufti menjadi 'pemimpin' untuk melakukan gerakan menghadapi Inggris melalui jalur diplomasi politik (Jumat, 2012). Pemikiran tersebut terbawa hingga ke Palu melihat kondisi umat Islam berada di bawah bayang-bayang kolonisasi dan imprealisasi. Kebebasan beragama secara sosial dan politis menjadi tujuan utama dalam setiap gerakannya. Dengan dasar pemikiran tersebut, sosok ini kemudian membangun lembaga pendidikan melalui lembaga intelektual pada 1929. Sebab pendidikan adalah cara yang paling kuat untuk membendung aktivitas kolonisasi Belanda di Nusantara. Melalui lembaga pendidikan beliau tetap menjalankan tarekat Alawiyyah pada beberapa muridnya, terutama terhadap Yamin Lasawedi. 
Tarekat Alawiyyah yang diwariskan oleh Sayyid Idrus bin Salim Aljufrie terlihat melalui aktivitas para pengikut tarekat yang mengungkapkan keinginan atau kegelisahan batinnya terkait dengan kebenaran ajaran agama. Dengan memahami keinginan dan kegelisahan jemaah, seorang murshid akan memberikan bimbingan secara spesifik kepada mereka, sehingga mereka dapat merasakan perubahan pada dirinya (Adnan, 2017). Pada akhirnya, kedua gerakan ini tidak hanya menghidupkan jejaring tarekat yang berkembang di Nusantara, namun juga menjadi jalan, thariq, bagi sālik untuk menghidupkan agama dan ibadah. Dengan cara seperti itu, seorang murshid berharap tertanam pada murid rasa yakin terhadap ajaran Islam yang menjadi sistem kepercayaan. Dengan kata lain, latihan spiritual itu dilakukan untuk mencapai derajat yang tinggi dan mulia di hadapan sang pencipta.

\section{Kesimpulan}

Tarekat Syattariyah dan Alawiyyah adalah bukti konkrit atas perkembangan dan warisan pemikiran di Sulawesi Tengah. Abdullah Raqie atau Dato Karama menjadi katalisator terkait pengenalan Islam di Sulawesi Tengah. Kedatangannya ke Sulawesi Tengah tidak lepas dari kondisi masyarakat Muslim yang berkembang. Di sisi lain, jejaring niaga membawanya pada wilayah Sulawesi Tengah dengan misi dakwah dan penyebaran Islam. Pengamalan Abdullah Raqie atas tarekat Syattariyah direfleksikan melalui misi dakwah yang adaptif, akomodatif, dan akulturatif. Dirinya tidak menghapus praktik pemikiran animisme dan dinamisme, namun mengalami proses adaptasi yang lebih halus di tengah masyarakat lokal di Sulawesi Tengah. Jejaring yang dibangunnya tidak hanya menjadi warisan pemikiran yang terus diingat oleh masyarakat lokal, namun dihidupkan dan dilestarikan sebagai bagian pengajaran dan aplikasi keagamaan. Relasinya yang terhubung ke Abdul Rauf As-Singkili, dan beberapa mursyid tarekat Syattariyah menjadikannya sebagai tokoh yang mengenalkan tarekat tersebut di Sulawesi Tengah. Pemikirannya mengajarkan masyarakat Muslim untuk megikuti ajaran Islam yang utuh. Dirinya menjadi pengejawantahan gerakan dan jejaring Islam revival yang membawa kesadaran umat untuk memeluk ajaran Islam.

Berbeda dengan Sayyid Idrus bin Salim Aljufrie yang menawarkan gerakan Islam yang modernis dan neo-revivalisme Islam. Gerakan pemikiran modernis dipraktikkan dalam dunia pendidikan melalui Al-Khairaat. Sosok ini menjadi tokoh sentral dalam gerakan Tarekat Alawiyyah di Sulawesi Tengah yang terhubung dengan para mursyid tarekat di Jawa, Kalimantan, dan kawasan Sulawesi. Gerakannya yang menginginkan Islam kembali pada ajaran murni merupakan satu wadah terhadap gerakan Neo-revivalisme di Sulawesi Tengah pada pertengahan abad XX. Tokoh yang mengakui dan mengikuti pemikirannya adalah Rustam Arsyad sebagai tokoh yang menawarkan reorientasi pola pikir umat Islam di Sulawesi Tengah kepada pemikiran Neo-revivalis. Bagi Sayyid Idrus bin Salim Aljufrie ilmu akan tetap bertahan dan berkembang sesuai syariah Islam, dan mampu merespon kebutuhan keummatan.

Pada akhirnya gerakan tarekat adalah wadah untuk menghidupkan dan mempertahankan kembali Islam di tengah masyarakat Muslim. Gerakan tarekat, meski inklusif, menjadi salah satu daya tarik bagi umat islam untuk mempertahankan eksistensi mereka dalam dunia pemikiran dan peradaban Islam. Tarekat Syattariyah dan Alawiyyah merupakan seklumit bukti konkrit atas perkembangan Islam. Keduanya merespon perkembangan dunia melalui dunia pemikiran melalui kelompok modernis, puritan, dan neorevivalis dalam pemikiran Islam di abad XX. 


\section{Daftar Pustaka}

Abdullah, M. D. (1975). Mengenal Tanah Kaili. Palu: Badan Pengembangan Pariwisata Dati I Sulawesi Tengah.

Abdullah, R., \& Masduki, M. (2017). Karakteristik Tafsir Nusantara (Studi Metodologis atas Kitab

Turjumun al-Mustafid Karya Syekh Abdurrauf al-Singkili). Jurnal Studi Ilmu-Ilmu Al-Qur'an

Dan Hadis, 16(2). https://doi.org/10.14421/qh.2015.1602-01

Adnan, A. (2017). Perjalanan Rohani Perspektif Kaum Sufi. Syifa Al-Qulub, 1(2), 11-21. https://doi.

org/10.15575/saq.v1i2.1428

Ali, A. H. (2010). Biografi Guru Tua. Palu: Edukasi Mitra Grafika.

Ali, M. (2014). Datuk Karama dan Islamisasi Masyarakat Kaili di Lembah Palu. Cirebon: Perwira.

Anto, J. (2015). Membaca Memori Dato Karama Lewat Politik Memori. Retrieved December 5, 2021, from

http://jefriantogie.blogspot.co.id

Asy'ari, P. M., \& Bahdar, B. (2019). Learning Model of Old Teachers (Sayyid Idrus Bin Salim Aljufri) in

Spreading Islam in Central Sulawesi. FITRAH:Jurnal Kajian Ilmu-Ilmu Keislaman, 5(2). https:// doi.org/10.24952/fitrah.v5i2.2001

Atikurrahman, M., Ilma, A. A., Dharma, L. A., Affanda, A. R., Ajizah, I., \& Firdaus, R. (2021). Sejarah

Pemberontakan dalam Tiga Bab: Modernitas, Belasting, dan Kolonialisme dalam Sitti

Nurbaya. SULUK: Jurnal Bahasa, Sastra, Dan Budaya, 3(1). https://doi.org/10.15642/

suluk.2021.3.1.1-22

Azis, A. (2016). Islamisasi Nusantara Perspektif Naskah Sejarah Melayu. THAQAFIYYAT: Jurnal Bahasa,

Peradaban Dan Informasi Islam, 16(1), 53-76. Retrieved from http://ejournal.uin-suka.ac.id/ adab/thaqafiyyat/article/view/623

Azis, M. N. I. (2021). Jaringan Tarekat: Pemikiran dan Gerakan Keagamaan Di Sulawesi Tengah Abad XIX-

XX M. Jurnal El-Tarikh, Journal of History, Culutre and Civilization, 2(1), 144-159. https://doi.

org/https://doi.org/10.24042/jhcc.v2i1.8456

Azra, A. (2002). Islam Nusantara: Jaringan Global dan Lokal. Bandung: Mizan.

Azra, A. (2006). Renaisans Islam Asia Tenggara: Sejarah Wacana dan Kekuasaan. Bandung: PT. Remaja

Rosdakarya.

Azra, A. (2013). Jaringan Ulama Timur Tengah dan Kepulauan Nusantara Abad XVII \& XVIII: Akar Pembaruan Islam Indonesia. Jakarta: Kencana Prenada Media Group.

Azra, A., \& Fathurrahman, 0. (2002). Jaringan Ulama. In Ensiklopedi Tematis Dunia Islam V (pp. 105-138). Jakarta: Ichtiar Baru van Hoeve.

Bruinessen, M. Van. (1995). Kitab Kuning, Pesantren, dan Tarekat: Tradisi-Tradisi Islam Di Indonesia. Mizan, II.

Churchill, W., Adriani, N., \& Kruijt, A. C. (1915). De Bare'e-Sprekende Toradja's van Midden-Celebes.

Bulletin of the American Geographical Society, 47(1). https://doi.org/10.2307/201144

Dalimunthe, L. A. (2016). Kajian Proses Islamisasi di Indones. Jurnal Studi Agama Dan Masyarakat, 12(1).

de Graaf, H. J. (2001). Kerajaan Islam Pertama: Tinjauan Sejarah Politik Abad XV dan XVI. Jakarta: Pustaka Utama Grafiti.

Fang, L. Y. (2011). Sejarah Kesusasteraan Melayu Klasik. Jakarta: Yayasan Obor Indonesia. 
Firdaus, F. (2018). Meretas Jejak Sufisme Di Nusantara. Al-Adyan: Jurnal Studi Lintas Agama, 13(2), 303337. https://doi.org/10.24042/ajsla.v13i2.3854

Geertz, C. (1982). Islam Yang Saya Amati: Perkembangan di Maroko dan Indonesia (Terjemahan). Jakarta: Yayasan Ilmu-Ilmu Sosial.

Haliadi, H. (2021). Karakteristik Ulama Penyiar Agama Islam di Palu. PUSAKA, 9(1). https://doi. org/10.31969/pusaka.v9i1.484

Hall, K. R., \& Reid, A. (1994). Southeast Asia in the Early Modern Era: Trade, Power, and Belief. Journal of the Economic and Social History of the Orient, 37(3). https://doi.org/10.2307/3632261

Howell, J. D. (2007). Modernity and Islamic Spirituality in Indonesia's New Sufi Networks. In Sufism and the 'Modern' in Islam. https://doi.org/10.5040/9780755607983.ch-012

Huda, N. (2007). Islam Nusantara: Sejarah Sosial Intelektual Islam di Indonesia. Yogyakarta: Ar-Ruzz Media. Ibrahim, U. (2001). Thariqah 'Alawiyyah: Napak Tilas dan Studi Kritis atas Sosok dan Pemikiran Allamah Sayyid 'Abdullah Al-Haddad, Tokoh Sufi Abad ke-17. Bandung: Mizan.

Johns, A. H. (1961). Sufism as a Category in Indonesian Literature and History. Journal of Southeast Asian History, 2(1). https://doi.org/10.1017/S0217781100000260

Johns, A. H. (1993). Islamization in Southeast Asia : Reflections and Reconsiderations with Special Reference to the Role of Sufism. The Southeast Asian Studies, 31(1). https://doi.org/10.20495/ tak.31.1_43

Johns, A. H. (1995). Sufism in Southeast Asia: Reflections and Reconsiderations. Journal of Southeast Asian Studies, 26(1). https://doi.org/10.1017/S0022463400010560

Jumat, G. (2012). Nasionalisme Ulama: Pemikiran Politik Kebangsaan Sayyid Idrus bin Salim Aljufri 18911969. Jakarta: Puslitbang Kementerian Agama RI.

Jung, C. G. (1969). The Archetypes and the Collective Unconscious (H. Read, Ed.). New Jersey: Princeton University Press.

Kadir, A. (2013). Sumbangan Sayyid Idrus Bin Salim Al-Jufri Dalam Pembinaan Syariat Islam Terhadap Masyarakat Lembah Palu dan Komunitas Muslim Indonesia. Semarang: Pustaka Zaman.

Kambay, S. B. (1991). Perguruan Islam Alkhairat Dari Masa Ke Masa. Palu: Tim Peneliti S.K.P.B. Al-Khairaat. Kartodirdjo, S. (1966). The Peasants' Revolt of Banten in 1888. https://doi.org/10.1163/9789004286788 Kartodirjo, S. (1982). Pemikiran dan Perkembangan Historiografi Indonesia: Suatu Alternatif. Jakarta: Gramedia.

Kharlie, A. T. (2006). Pergumulan Pemikiran Mistiko Filosofi di Nusantara Abad 16-18 M. ALQALAM, 23(2). https://doi.org/10.32678/alqalam.v23i2.1498

Kotilainen, E.-M. (1992). When the Bomes are Left: A Study of Material Culture of Central Sulawesi. Helsinki: The Finnsh Antropological Society.

Kruyt, A. C. (1938). De West-Toradjas op Midden-Celebes. Amsterdam: Noord-Hollandsche Uitg.Maatschappij.

Kuntowijoyo, K. (2006). Islam sebagai Ilmu: Epistiomologi, Metodologi, dan Etika. Yogyakarta: Tiara Wacana.

Laffan, M. (2015). Sejarah Islam di Nusantara (Terjemahan; I. Aunullah \& R. N. Badariah, Eds.). Yogyakarta: PT. Bentang Pustaka. 
Mahid, S. (2009). Sejarah Sosial Sulawesi Tengah. Palu: Pilar Media.

Mahid, S., Andriansyah, A., \& Wekke, I. S. (2018). Arab Community Encounter With Kaili Culture in Education and Da'wah. EL HARAKAH (TERAKREDITASI), 20(1). https://doi.org/10.18860/ el.v20i1.4788

Mardiono, P. (2020). Melacak Gerakan Perlawanan dan Laku Spiritual Pangeran Diponegoro. Yogyakarta: Araska.

Nadjamudin, L. (2016). History of Buol : Study on The Border Territory and Exploitation of Mine.

Proceedings of the 1st UPI International Conference on Sociology Education (UPI ICSE 2015). https://doi.org/10.2991/icse-15.2016.76

Nurdin, N., \& Maddini, H. (2018). Sejarah Dakwah Dato Karama: Menelusuri Ulama Sumatera Barat Penyebar Islam di Lembah Palu. Al-Mishbah, 14(2), 205-239. https://doi.org/https://doi. org/10.24239/al-mishbah.Vol14.Iss2.119

Rasyid, L. A., Supriadi, S., \& Aisa, S. (2018). Pemikiran dan Peranan Sayyid Idrus Bin Salim Aljufri terhadap Perkembangan Pendidikan Islam di Manado. Journal of Islamic Education Policy. https://doi.org/10.30984/j.v3i1.857

Rasyid, N. A., \& Nurdin, N. (2021). The diaspora of the sufis in Indonesia: Moving from western to eastern islands. International Journal of History and Philosophical Reasearch, 9(1).

Reid, A. (2011). Asia Tenggara dalam Kurun Niaga 1450-1680: Jaringan Perdagangan Global Asia Tenggara. Jakarta: Yayasan Pustaka Obor Indonesia.

Ridgeon, L. (2014). Mysticism in Medieval Sufism. In The Cambridge Companion to Sufism (pp. 125-149). https://doi.org/10.1017/CC09781139087599.009

Roesli, M. (2011). Sitti Nurbaya (Kasih Tak Sampai) (Empat Puluh Tujuh). Jakarta: Balai Pustaka.

Rosatria, E. (1996). Islamization and islamic learning in the sultanate of aceh. Studia Islamika, 3(1). https:// doi.org/10.15408/sdi.v3i1.815

Rozehnal, R. (2016). Islamic Sufism Unbound: Politics and Piety in Twenty-First Century Pakistan.

Retrieved from https://www.google.co.id/books/edition/Islamic_Sufism_Unbound/aoYDAAAQBAJ?hl=en $\& g b p v=0$

Salleh, R. M., Bakar, A. A., Abdullah, M. S. Y., Berhan, A. Bin, Bin Othman, S. H., Halim, A. H. A., ... Ali, A. (2019). Crimes from the Perspective of Shaykh Abdul Rauf Bin Ali Al-Fansuri Al-Singkili in Manuskrip Mir'At Al-Tullab: A Perfect Introduction. Journal of Advanced Research in Dynamical and Control Systems, 11(8 Special Issue).

Shihab, A. (2009). Akar Tasawuf di Indonesia: Antara Tasawuf Sunni dan Tasawauf Falsafi. Jakarta: Pustaka Iman.

Suryadi, S. (2004). Syair Sunur: Teks dan Konteks Otobiografi Seorang Ulama Minangkabau Abad Ke-19. Padang: Citra Budaya.

Syawal, I. (2019). Syekh Abdullah Raqi: Orang Minangkabau Islam di Palu Pada Abad XVII. JURNAL PENELITIAN SEJARAH DAN BUDAYA, 5(2). https://doi.org/10.36424/jpsb.v5i2.131

Taufani, T. (2018). Pengaruh Sufisme di Indonesia. Potret Pemikiran, 20(1). https://doi.org/10.30984/ pp.v20i1.750 
Tjandrasasmita, U. (1975). Art de Mojopahit et art du Pasisir. Archipel, 9(1). https://doi.org/10.3406/ arch.1975.1222

Wink, A. (1996). Merchants and Faith: Muslim Commerce and Culture in the Indian Ocean. Pacific Affairs, 69(2), 254. https://doi.org/10.1353/jwh.2005.0073

1 Dato Karama, bernama asli Abdullah Raqie, dan Dato Mangadji, diperkirakan telah tiba di Sulawesi Tengah pada awal abad XVII. Dia merupakan seorang ulama, dan mungkin juga utusan, yang datang dari Minangkabau. Apabila melihat masa keberadaannya di Sulawesi Tengah yakni awal abad XVII, ada kemungkinan Dato Karama memiliki keterikatan dan keterhubungan dengan tiga ulama penyebar Islam di Sulawesi Selatan, Dato ri Bandang (Abdul Makmur), Dato Patimang (Sulaiman), dan Dato ri Tiro (Abdul Jawad). Hal ini diperkuat melalui gelar 'Dato' yang disandang oleh Abdullah Raqie, berciri khas berasal dari Tanah Melayu atau Sumatera, sedangkan kata 'Karama' diperoleh dari penyebutan lokal mengenai keistimewaannya. Selain itu, kedatangan tiga ulama di Sulawesi Selatan pada awalnya berada di Luwu sekitar tahun $1603 \mathrm{M}$ dan diperkuat melalui penerimaan Islam pertama kali di Luwu yang bertahun 1603 M (Nurdin \& Maddini, 2018).

2 Jika membaca Tenggelamnya Kapal van der Wijk (1938) yang digubah oleh Haji abdul Malik Karim Amrullah (HAMKA) rasanya tidak mengherankan apabila kemudian latar cerita awal ditempat di Sulawesi, tepatnya Makassar. Dalam konteks roman, Pendekar Sutan, ayahanda protagonis Zainuddin merantau dari Minangkabau ke Sulawesi. Anasir-anisir tersebut memberikan konteks historis hubungan dua pulau besar Nusantara, Sumatera dan Minangkabau. Dalam perspektif Jung (1969) pengalaman masa silam yang historis menjadi arketip yang mempengaruhi pengarang sastra untuk mengubah karya mereka.

3 Abdullah Lasawedi merupakan anak dari H. Amin Lasawedi, murid sekaligus sahabat dari Sayyid Idrus bin Saslim Aljufrie. Abdullah Lasawedi juga pernah belajar langsung di Sekolah Alkhairaat di Palu dan menjadi salah satu saksi sejarah dalam aktivitas pendidikan Islam yang dikembangkan oleh Sayyid Idrus bin Salim Aljuufri, gurunya, dan Amin Lasawedi, ayahnya.

$4 \quad$ Perang Kamang (1908), misalnya, seperti digambarkan secara apik dan samar oleh Marah Rusli dalam tiga bab (14-16) terakhir Sitti Nurbaya memberikan ilustrasi seputar peristiwa resistensi penduduk lokal atas kebijakan pemerintah kolonial Hindia Belanda. Dalam hal itu, penduduk pedalaman (desa) Minangkabau menolak dan lantas memberontak atas penerapan pajak perorangan (Belasting). Gerakan massal tersebut dimotori oleh para haji dan ulama setempat yang notabene bermukim di pedalaman Minangkabau (Atikurrahman et al., 2021). Sedangkan pemberontakan petani Banten (1888) tak lebih sama, bahwa kebijakan pemerintah kolonial setempat telah memicu sikap perlawanan penduduk desa untuk melawan kebijakan pemerintah. Seperti halnya perang Kamang, pemberontakan petani di Banten juga dimotori oleh para Haji dan ulama yang sempat melakukan lawatan ke Timur Tengah (Kartodirdjo, 1966).

5 Kyai Modjo dikenal sebagai mursyid tarekat Syattariyah melalui kitab pegangan yang digunakannya dalam bergerilya yakni Fath al-Wahhab (Mardiono, 2020). Fakta menarik seputar kehidupan tangan kanan Pangeran Diponegoro pasca Perang Jawa, bahwa sosok ikonik abad XIX ini diminta oleh 
kolonial untuk membantu mereka memadamkan perlawanan di Minangkabau. Semula, Kyai Modjo menjadi musuh para sabil gerakan Paderi sebelum akhirnya berbalik melawan pemerintah kolonial. Konon, Marah Rusli merupakan keturunan dari sosok kharismatik Perang Jawa ini. Dia mendapatkan jalur keturunan dari ibunya (lih. biografi Marah Rusli dalam Sitti Nurbaya (Roesli, 2011). 